\title{
Evaluation of Anti-Diabetic Activity of the Plant Leaves of Verbascum thapsus in Alloxan Induced Diabetic Rats
}

\section{Anusha Pothamsetty ${ }^{1}$, M. Janarthan', Md. Faheemuddin ${ }^{1 *}$, Mohsina Hussain ${ }^{2}$, Md. Mazher Ahmed $^{3}$}

\begin{abstract}
${ }^{1}$ Department of Pharmacology, Nimra College of Pharmacy, Jawaharlal Nehru Technical University Kakinada, Kakinada533003, Andhra Pradesh, India

${ }^{2}$ Department of Pharmacy Practice, Smt. Sarojini Ramulamma college of pharmacy, Palamur University, Mahbubnagar509001, Telangana, India

${ }^{3}$ Department of Pharmaceutics, Luqman College of Pharmacy, Gulbarga 585101, Karnataka, India
\end{abstract}

*Corresponding author: Faheemuddin M, Department of Pharmacology, Nimra College of Pharmacy, Jawaharlal Nehru Technical University Kakinada, Kakinada-533003, Andhra Pradesh, India, E-mail: faheemuddin.md4u@gmail.com

Received: May 25, 2017; Revised: September 29, 2017; Published: October 10, 2017

Copyright: (C2017 Pothamsetty A, et al. This is an open-access article distributed under the terms of the Creative Commons Attribution License, which permits unrestricted use, distribution, and reproduction in any medium, provided the original author and source are credited. The article has been previewed and authenticated by the Authors before sending the publication for print. The Journal, Editor and the Editorial Board are not entitled or liable to either justify or responsible for inaccurate and misleading data if any. It is the sole responsibility of the Author concerned.

Citation: Pothamsetty A, Janarthan M, Faheemuddin M, et al. Evaluation of Anti-Diabetic Activity of the Plant Leaves of Verbascum thapsus in Alloxan Induced Diabetic Rats. Int J Pharm Pharmacol 2017; 1: 118. doi: $10.31531 / 2581-3080.1000118$

\begin{abstract}
Objective: To evaluate the anti-diabetic activity of ethanolic extract of Verbascum thapsus (L) on alloxan induced diabetic rats.

Methods: Diabetes was induced in Wistar rats by intraperitoneal injection of alloxan monohydrate (100 mg/kg b.w/i.p). Ethanolic extract of Verbascum thapsus (L) (250, $500 \mathrm{mg} / \mathrm{kg} \mathrm{b.w/p.o)} \mathrm{was}$ prepared freshly, administered to alloxan induced diabetic rats for 21 days. Blood glucose levels monitored at 1, 3, 7, 14 and 21 days, serum lipid profile and Histopathological changes in pancreas were examined after 21 days. OGTT was performed by administration of 250 and $500 \mathrm{mg} / \mathrm{kg} \mathrm{b} . \mathrm{w} / \mathrm{p}$.o of ethanolic extract of Verbascum thapsus $(L)$ and $10 \mathrm{mg} / \mathrm{kg}$ b.w/p.o of Glibenclamide to different groups respectively in normal rats.

Results: Significant $(p<0.001)$ results were observed in the estimated parameters like reduction in blood glucose, elevated cholesterol, triglyceride, VLDL, LDL levels and also increase in the levels of $H D L$ were observed in diabetic rat's treatment after 21 days of extract. The treatment produced protective effect of $\beta$-cells of Langerhans of pancreas in rats by histopathological studies. Oral glucose tolerance test, blood glucose levels significantly lower at all time points (In extract and standard Wistar rats) that blood was sampled after oral glucose load.

Conclusion: The results were suggested that the whole plant extract of Verbascum thapsus $(L)$ having potent Antidiabetic activity on alloxan-induced diabetic rats and this justifies its use in ethanomedicine and can be exploited in the management of diabetes.

Keywords: Verbascum thapsus, Alloxan, Diabetic rats, Glibenclamide
\end{abstract}




\section{Introduction}

Diabetes mellitus is a group of metabolic disorders in which a person has high blood sugar, either body does not produce enough insulin, or cells do not respond to the insulin that is produced [1-3]. Globally, as of 2010, an estimated 285 million people had diabetes, with type 2 making up about $90 \%$ of the cases. Its incidence is increasing rapidly, and by 2030 , this number is estimated to almost double [1-3].

Medicinal plants have been used for centuries as remedies for human diseases because they contain components of therapeutic value. About $75-80 \%$ of the world population, mainly in the developing countries still use plant based medicines for primary health care [4]. Based on a large number of chemical and pharmacological research work, numerous bioactive compounds have been found in medicinal plants for diabetes. A number of investigators have shown that cumarins, flavonoids, terpenoids, and a host of other secondary plant metabolites, including arginine and glutamic acid, possess hypoglycemic effect in various experimental models $[5,6]$. Therefore, treating diabetes mellitus with plant derived compounds which are accessible and do not require laborious pharmaceutical synthesis seems highly attractive [7].

\section{Materials and Methods}

The plant Verbascum thapsus Fresh leaves are collected from Sri Venkateshwara University Tirupati, India. The plant was authenticated by Dr. Madhava Chetty, Department of Botany and voucher specimen of the plant were preserved at institute herbarium library.

\section{Preparation of plant extract}

Fresh plants leaves were collected, washed to remove adhered dirt, rinsed with distilled water, blotted and dried in shade. The shadedried specimens were powdered in a mixer. This powder was subjected to Soxhlet extraction using 70\% ethanol as solvent. This cycle was repeated many times, over hours or a few days. The extracts were concentrated under reduced pressure and preserved in refrigerator until further use. At the end of the hot extraction process each extract was filtered.
The extracts were then kept in desiccators to remove remaining moisture, if present, and finally stored in air tight containers at $4^{\circ} \mathrm{C}$ for further use [8].

\section{Phytochemical screening}

Phytochemical screening of crude extract was carried out employing standard procedures to reveal the presence of chemical constituents such as alkaloids, flavonoids, tannins, saponins, Tannins, glycosides, carbohydrates and others [9].

\section{Animals}

Healthy adult male Wistar rats of 150-180 gm were selected for the study. The animals were housed in standard cages and kept under standard condition. They were given a standard diet and water ad libitum. Animal studies had approval of IAEC, Nimra College of Pharmacy constituted by Committee for the Purpose of Control and Supervision of Experiments on Animals (CPCSEA) $[8,10,11]$.

\section{Determination of acute oral toxicity studies}

The LD (50) of the extract was determined by using wistar rats. Rats were kept for overnight fasting prior to drug administration. A total of five animals were used, which received a single oral dose $(2000 \mathrm{mg} / \mathrm{kg} / \mathrm{b} . \mathrm{w})$ of Verbasum thapsus extract. After the administration of extract food was withheld for further 3-4 h. Animals were observed individually at least once during the first $30 \mathrm{~min}$ after dosing, periodically during the first $24 \mathrm{~h}$ and daily therefore for a period of 14 days [8.12].

\section{Hypoglycemic activity in normal rats (OGTT) and Alloxan induced diabetic rats: Oral Glucose Tolerance Test (OGTT)}

In five groups (each group of $\mathrm{N}=6$ ) overnight fasted normal animals the Oral glucose tolerance test (OGTT) was performed. $1^{\text {st }}$ group was administered with distill water, $2^{\text {nd }}$ group was given glucose $2 \mathrm{mg} / \mathrm{kg}$ b.w and the following group were treated with following treatment to one hour previously administration of glucose $3^{\text {rd }}$ group was treated with glibenclamide $(10 \mathrm{mg} / \mathrm{kg} \mathrm{bw}) 4^{\text {th }}$ and $5^{\text {th }}$ group 
was administered with $250 \mathrm{mg} / \mathrm{kg}$ b.w 500 $\mathrm{mg} / \mathrm{kg}$ b.w ethanolic extract of Verbascum thapsus. Table 1 showed the blood glucose levels of the Normal control (Normal saline 0.5 $\mathrm{ml} / \mathrm{kg}$ b.w/p.o), Glibenclamide $(10 \mathrm{mg} / \mathrm{kg}$ b.w/p.o) and ethanolic extract of Verbascum thapsus (250 mg and $500 \mathrm{mg} / \mathrm{kg}$ b.w/p.o) at different time points $(0,30,60,120,180 \mathrm{~min})$ after oral administration of glucose $(2 \mathrm{~g} / \mathrm{kg}$ b.w/p.o). Blood was withdrawn from the tail vein glucose levels were estimated using Gluco check blood glucose monitoring kit. There was a peak increase in the blood glucose at $30 \mathrm{~min}$ in all the groups [13].

Table 1: Blood glucose levels of the Normal control, Glibenclamide and ethanolic extract of Verbascum thapsus

\begin{tabular}{|c|c|c|c|c|c|}
\hline \multirow{3}{*}{ Group } & \multicolumn{5}{|c|}{ Blood glucose level (mg/dL) } \\
\hline & 0 Min & 30 Min & 60 Min & 120 Min & 180 Min \\
\hline & $\begin{array}{c}\text { Mean } \pm \\
\text { SEM }\end{array}$ & $\begin{array}{c}\text { Mean } \pm \\
\text { SEM }\end{array}$ & $\begin{array}{c}\text { Mean } \pm \\
\text { SEM }\end{array}$ & $\begin{array}{c}\text { Mean } \pm \\
\text { SEM }\end{array}$ & $\begin{array}{c}\text { Mean } \pm \\
\text { SEM }\end{array}$ \\
\hline $\begin{array}{c}\text { I-Normal } \\
\text { normal Saline }(0.5 \mathrm{ml} / \mathrm{kg} \\
\text { b.w/p.o })\end{array}$ & $\begin{array}{c}82.8 \pm \\
1.35\end{array}$ & $\begin{array}{c}85.0 \pm \\
1.95 * * *\end{array}$ & $\begin{array}{c}82.0 \pm \\
1.91 * * *\end{array}$ & $\begin{array}{c}80.0 \pm \\
1.64 * * *\end{array}$ & $\begin{array}{c}79.0 \pm \\
1.11 * * *\end{array}$ \\
\hline $\begin{array}{l}\text { II-Control (oral glucose of } 10 \\
\text { mg/kgb.w/p.o) }\end{array}$ & $\begin{array}{l}84.6 \pm \\
1.645\end{array}$ & $\begin{array}{l}121.0 \pm \\
1.2 * * *\end{array}$ & $\begin{array}{l}145.0 \pm \\
1.54 * * *\end{array}$ & $\begin{array}{l}140.0 \pm \\
1.75^{* * *}\end{array}$ & $\begin{array}{l}138.0 \pm \\
1.45^{* * *}\end{array}$ \\
\hline $\begin{array}{c}\text { III-Standard } \\
\text { Glibenclamide }(10 \mathrm{mg} / \mathrm{kg} \\
\text { b.w/p.o })\end{array}$ & $\begin{array}{c}83.8 \pm \\
1.35\end{array}$ & $\begin{array}{l}125.0 \pm \\
1.2 * * *\end{array}$ & $\begin{array}{l}134.0 \pm \\
1.54 * * *\end{array}$ & $\begin{array}{l}112.0 \pm \\
1.65^{* * *}\end{array}$ & $\begin{array}{l}82.0 \pm \\
0.856\end{array}$ \\
\hline $\begin{array}{l}\text { IV-Extract Treated } \\
(250 \mathrm{mg} / \mathrm{kg} \text { b.w/p.o })\end{array}$ & $\begin{array}{c}83.0 \pm \\
1.83\end{array}$ & $\begin{array}{l}122.0 \pm \\
1.62 * * *\end{array}$ & $\begin{array}{c}135.0 \pm \\
0.989 * * *\end{array}$ & $\begin{array}{l}107.0 \pm \\
1.48 * * *\end{array}$ & $96.5 \pm 0.764$ \\
\hline $\begin{array}{c}\text { V-Extract Treated } \\
(500 \text { mg/kg b.w/p.o) }\end{array}$ & $\begin{array}{c}80.7 \pm \\
1.31\end{array}$ & $\begin{array}{l}105.0 \pm \\
2.16^{* * *}\end{array}$ & $\begin{array}{l}123.0 \pm \\
1.67 * * *\end{array}$ & $\begin{array}{c}97.7 \pm \\
0.882 * * *\end{array}$ & $\begin{array}{l}81.7 \pm \\
1.12 * *\end{array}$ \\
\hline
\end{tabular}

Values are Mean \pm SEM; $\mathrm{n}=6 ; * \mathrm{P}$ value $<0.01 ; * * \mathrm{p}<0.05 ; * * * \mathrm{p}<0.001$ vs. $0 \mathrm{~min} ; \mathrm{mg} / \mathrm{kg}$ b.w/p.o: milligram per kilogram of body weight per oral.

\section{Induction of diabetes and treatment}

Healthy Wistar strain albino rats were selected and randomly divided into different groups with six animals in each group serving as group 'A'=normal, Control group='B', Standard= group ' $\mathrm{C}$ ', Group ' $\mathrm{D}$ '=Ethanolic extract, 250 $\mathrm{mg} / \mathrm{kg}$ b.wt; group ' $\mathrm{E}$ '=Ethanolic extract, 500 $\mathrm{mg} / \mathrm{kg}$ b.wt. Alloxan monohydrate was first weighed individually for each animal according to its weight and then solubilised with $0.2 \mathrm{ml}$ saline just prior to injection (Table 2). Diabetes Pothamsetty A, et al. Int J Pharm Pharmacol was induced by injecting it at a dose of 100 $\mathrm{mg} / \mathrm{kg}$ b.w/i.p. After $1 \mathrm{~h}$ of alloxan administration, the animals were given feed $a d$ libitum and 5\% dextrose solution was also given in feeding bottle for a day to overcome the early hypoglycemic phase. The animals were kept under observation, and after $48 \mathrm{~h}$, blood glucose was measured. One group served as a control which received vehicle alone. The diabetic rats (glucose level $>150 \mathrm{mg} / \mathrm{dL}$ ) were separated and divided into different groups for experimental study [14]. 


\section{Measurement of serum lipid profile}

The serum from the blood was separated as

\section{Histopathological studies}

At the end of the study i.e. on $28^{\text {th }}$ day the rats were sacrificed and the tissues (pancreas) were collected. The whole histopathological process was carried out in accordance with the SOPs (Standard Operating Procedures) (Tissue fixation, Processing and Embedding) [17,18]. under: Sample was collected (preferably in eppendorf tubes) The serum was centrifuged at $1000 \mathrm{rpm}$ for $5 \mathrm{~min}$. The serum was pipette out using a micropipette. The serum was labeled with the animal number and the estimations were made. The serum glucose level and the lipid profile (total cholesterol HDL, LDL, VLDL and triglyceride level) was determined enzymatically on prietest bio chemistry analyser $[15,16]$.

Table 2: Effect of treatment on Alloxan induced diabetic rat

\begin{tabular}{|c|c|c|c|c|c|c|c|c|}
\hline \multirow{3}{*}{ Group } & \multicolumn{8}{|c|}{ Blood glucose level (mg/dL) } \\
\hline & 0 day & & $1^{\text {st day }}$ & $3^{\text {rd }}$ day & & $7^{\text {th }}$ day & $14^{\text {th }}$ day & $21^{\text {st }}$ day \\
\hline & $\begin{array}{l}\text { Mean } \\
\text { SEM }\end{array}$ & & $\begin{array}{l}\text { Mean } \\
\text { SEM }\end{array}$ & $\begin{array}{l}\text { Mean } \\
\text { SEM }\end{array}$ & & $\begin{array}{l}\text { Mean } \quad \pm \\
\text { SEM }\end{array}$ & $\begin{array}{l}\text { Mean } \quad \pm \\
\text { SEM }\end{array}$ & $\begin{array}{l}\text { Mean } \pm \\
\text { SEM }\end{array}$ \\
\hline $\begin{array}{l}\text { I } \\
\text { (Normal control) }\end{array}$ & $\begin{array}{l}88.00 \\
2.408\end{array}$ & & $\begin{array}{l}86.83 \\
2.344\end{array}$ & $\begin{array}{l}86.50 \\
2.349\end{array}$ & \pm & $\begin{array}{ll}87.00 & \pm \\
2.366 & \end{array}$ & $\begin{array}{l}87.17 \\
2.088\end{array}$ & $\begin{array}{ll}86.67 & \pm \\
2.319 & \end{array}$ \\
\hline $\begin{array}{l}\text { II } \\
\text { (Diabetic control) }\end{array}$ & $\begin{array}{l}241.8 \\
2.638\end{array}$ & \pm & $\begin{array}{l}246.3 \\
2.431\end{array}$ & $\begin{array}{l}256.8 \\
2.638\end{array}$ & \pm & $\begin{array}{ll}270.3 & \pm \\
2.404 & \end{array}$ & $\begin{array}{l}283.0 \\
2.817\end{array}$ & $\begin{array}{l}313.8 \pm \\
4.301\end{array}$ \\
\hline III (Standard) & $\begin{array}{l}217.80 \\
2.561\end{array}$ & & $\begin{array}{l}194.30 \\
2.692 * * *\end{array}$ & $\begin{array}{l}170.20 \\
2.822 * * *\end{array}$ & & $\begin{array}{l}142.30 \pm \\
2.813 * * *\end{array}$ & $\begin{array}{l}119.80 \pm \\
1.815^{* * *}\end{array}$ & $\begin{array}{l}86.67 \pm \\
4.104 * * *\end{array}$ \\
\hline IV (Test-I) & $\begin{array}{l}230.0 \\
4.367\end{array}$ & & $\begin{array}{l}217.6 \\
4.151\end{array}$ & $\begin{array}{l}204.7 \\
4.631 * *\end{array}$ & & $\begin{array}{l}183.7 \pm \\
4.773 * * *\end{array}$ & $\begin{array}{l}163.3 \pm \\
4.566 * * *\end{array}$ & $\begin{array}{l}134.8 \pm \\
4.377 * * *\end{array}$ \\
\hline V (Test II) & $\begin{array}{l}232.20 \\
3.270\end{array}$ & & $\begin{array}{l}218.2 \\
3.198 *\end{array}$ & $\begin{array}{l}192.2 \\
3.420 * * *\end{array}$ & & $\begin{array}{l}159.3 \pm \\
5.162 * * *\end{array}$ & $\begin{array}{l}122.7 \quad \pm \\
2.616^{* * *}\end{array}$ & $\begin{array}{l}89.67 \pm \\
3.844 * * *\end{array}$ \\
\hline
\end{tabular}

\section{Statistical analysis}

The values obtained from the biochemical analysis were expressed as mean \pm standard Error of Mean (S.E.M) and was subjected to ANOVA analysis using Dunnett's $t$-test [8].

\section{Result}

The ethanolic extract of Verbascum thapsus shown the presence of Carbohydrates, Flavonoids, Alkaloids, Terpenoids, Tannins, Steroids and Glycosides.

\section{Toxicity study}

In toxicity study (limit test) the ethanolic extract Verbascum thapsus was shown no signs and symptoms, morbidity and mortality on Wistar rats. 


\section{Oral Glucose Tolerance Test (OGTT)}

In the Oral glucose tolerance test (OGTT) in normal rats Table 1 showed the blood glucose levels of the Normal control (Normal saline 0.5 $\mathrm{ml} / \mathrm{kg} \quad$ b.w/p.o $)$, Glibenclamide $(10 \mathrm{mg} / \mathrm{kg}$ b.w/p.o) and ethanolic extract of Verbascum thapsus $(250 \mathrm{mg}$ and $500 \mathrm{mg} / \mathrm{kg}$ b.w/p.o) at different time points $(0,30,60,120,150 \mathrm{~min})$ after oral administration of glucose $(2 \mathrm{~g} / \mathrm{kg}$ b.w/p.o). There was a peak increase in the blood glucose at $30 \mathrm{~min}$ in all the groups.

\section{Serum lipid profile}

In serum profile the elevated cholesterol, triglycerides, VLDL, LDL levels and decreased HDL levels were reported in the diabetic rats. In this study administration of extract of Verbascum thapsus (L). Table 3 showed significantly reduced the elevated cholesterol, triglycerides, VLDL and LDL levels in diabetic rats. Also increased the levels of HDL were observed in diabetic rats.

Histopathology examination of pancreas section, In the diabetic group, decrease in pancreatic islet numbers and size, atrophy and vacuolation, and damage of islets was detected, but these abnormal histological signs dramatically decreased in the group treated with standard and extract (i.e. regeneration of islets).

The plant leaves of Verbascum thapsus (L) contains carbohydrates, flavonoids, alkaloids, tannins, terpenoids, steroids and glycosides. Some of these classes of compounds have been

Table 3: Effect of treatment on Serum profile of different groups in diabetic rat

\begin{tabular}{|c|c|c|c|c|c|}
\hline \multirow{3}{*}{ Group } & \multicolumn{5}{|c|}{ Serum lipid profile (mg/dl) } \\
\hline & $\begin{array}{c}\text { Total } \\
\text { cholesterol }\end{array}$ & Triglycerides & HDL & LDL & VLDL \\
\hline & Mean \pm SEM & Mean \pm SEM & Mean \pm SEM & Mean \pm SEM & $\begin{array}{c}\text { Mean } \pm \\
\text { SEM }\end{array}$ \\
\hline $\begin{array}{l}\text { I } \\
\text { (Normal } \\
\text { control) }\end{array}$ & $63.2 \pm 2.280$ & $60.4 \pm 1.47$ & $33.0 \pm 1.040$ & $18.1 \pm 2.500$ & $12.1 \pm 0.293$ \\
\hline $\begin{array}{l}\text { II } \\
\text { (Diabetic } \\
\text { control) }\end{array}$ & $158.0 \pm 1.900$ & $144.0 \pm 4.87$ & $14.3 \pm 0.282$ & $114.0 \pm 1.820$ & $28.8 \pm 0.973$ \\
\hline $\begin{array}{l}\text { III } \\
\text { (Standard) }\end{array}$ & $73.6 \pm 1.130 * * *$ & $\begin{array}{ll}63.9 & \pm \\
2.19 * * * & \end{array}$ & $\begin{array}{ll}26.2 & \pm \\
1.500 * * * & \end{array}$ & $\begin{array}{ll}34.6 & \pm \\
1.230 * * * & \end{array}$ & $\begin{array}{ll}12.8 & \mathbf{\pm} \\
0.438 * * * & \end{array}$ \\
\hline $\begin{array}{l}\text { IV } \\
\text { (Test-I) }\end{array}$ & $92.5 \pm 2.030 * * *$ & $\begin{array}{ll}95.7 & \pm \\
1.42 * * * & \end{array}$ & $\begin{array}{ll}20.8 & \mathbf{\pm} \\
0.801 * * & \end{array}$ & $\begin{array}{ll}52.6 & \pm \\
2.520 * * * & \end{array}$ & $\begin{array}{ll}19.1 & \pm \\
0.283^{* * *} & \end{array}$ \\
\hline $\begin{array}{l}\mathrm{V} \\
\text { (Test II) }\end{array}$ & $75.1 \pm 1.590 * * *$ & $\begin{array}{ll}65.3 & \pm \\
1.86^{* * *} & \end{array}$ & $\begin{array}{ll}25.8 & \pm \\
1.380 * * * & \end{array}$ & $\begin{array}{ll}36.2 & \mathbf{\pm} \\
2.240 * * * & \end{array}$ & $\begin{array}{l}13.1 \quad \pm \\
0.373 * * *\end{array}$ \\
\hline
\end{tabular}

implicated in the antidiabetic activity of the plants. Ex: Flavonoids and tannins. The ethanolic extract of Verbascum thapsus (L) was shown significant antidiabetic activity when 
compared to standard drug glibenclamide 10 $\mathrm{mg} / \mathrm{kg} \mathrm{b.w/p.o} \mathrm{in} \mathrm{alloxan} \mathrm{induced} \mathrm{diabetic}$ Wistar rats.

In toxicity study (limit test) the ethanolic extract Verbascum thapsus (L) was shown no signs and symptoms, morbidity and mortality on Wistar rats.

In OGTT there was a peak increase in the blood glucose at $30 \mathrm{~min}$ in all the groups. In Glibenclamide and Extract treated groups, there was a decrease in blood glucose level at 180 min when compared to control group.

In Alloxan induced diabetic rats, the extract at doses of 250 and $500 \mathrm{mg} / \mathrm{kg}$ b.w/p.o showed a significant reduction in the blood sugar level after 3 rd day and $1^{\text {st }}$ day respectively.

At the end of the study the extract at dose of 250 and $500 \mathrm{mg} / \mathrm{kg}$ b.w $/ \mathrm{p} .0$ showed a significant $(\mathrm{p}<0.001)$ reduction in the blood glucose level comparable with that of glibenclamide $(10 \mathrm{mg} / \mathrm{kg} \quad$ b.w/p.o $)$ treated group.

In serum lipid profile the elevated cholesterol, triglyceride, VLDL, LDL levels and decreased HDL levels were reported in diabetic rats. In this study administration of extract of Verbascum thapsus (L) significantly reduced the elevated cholesterol, triglyceride, VLDL and LDL levels in diabetic rats. Also increased the levels of HDL were observed in diabetic rats. Therefore, this plant extract may be helps in preventing the diabetic associated complications.

From the histopathological studies, it was suggested that $\beta$ cells destruction by alloxan was inhibited, this might be the primary cause for the antidiabetic activity of the extracts (Figure 1). There is no destruction of $\beta$ cells in normal control group, complete damage of $\beta$ cells was observed in diabetic control group, and less cellular damage of beta cells was observed in all extract test groups and standard group but better in test-II $(500 \mathrm{mg} / \mathrm{kg}$ b.w/p.o) when compared to diabetic control group i.e. equal to that of standard drug treated group.

The Verbascum thapsus (L) extract $(500 \mathrm{mg} / \mathrm{kg}$ b.w/p.o) was shown a better significant antidiabetic activity. In Alloxan induced diabetic rats, the extract at dose of $500 \mathrm{mg} / \mathrm{kg}$ b.w/p.o showed a significant blood glucose reduction from 1 st day of treatment. The damage of $\beta$-cells of pancreas in alloxan induced diabetic control rats and regeneration of $\beta$-cells by standard rats was observed.

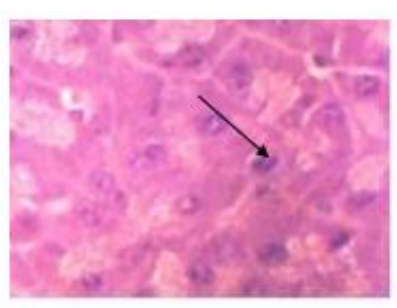

Normal control

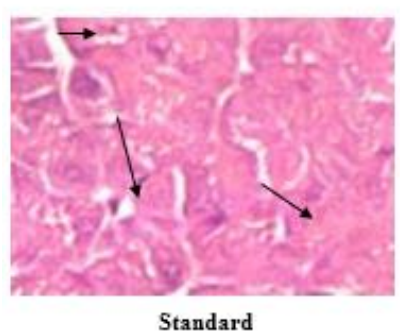

Standard

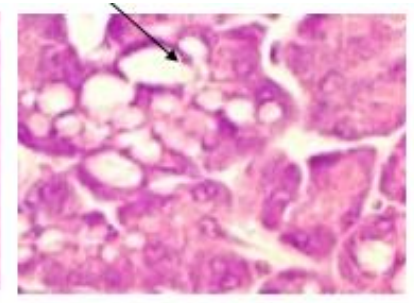

Diabetic control

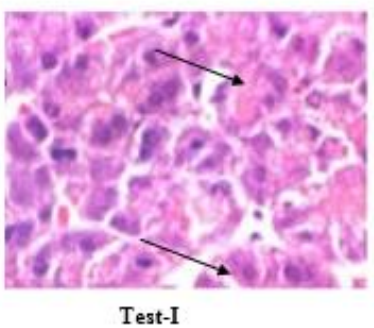

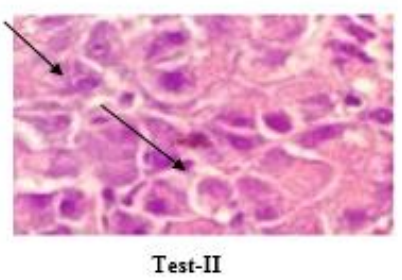

Figure 1: Histopatological changes in rat pancreas

The protection of beta cells was also shown by ethanolic extracts of Verbascum thapsus (L). Hence the above discussion revels that ethanolic extract at test-II $(500 \mathrm{mg} / \mathrm{kg}$ b.w/p.o) is effective and shows similar curative effect as standard (glibenclamide $10 \mathrm{mg} / \mathrm{kg}$ b.w/p.o).

Overall the present investigation has shown the presence of active phytochemicals in the ethanolic extract of Verbascum thapsus (L) and rich mixture of flavonoids, Tannins and Terpenoids components have significant antidiabetic activity.

\section{Conclusion}

It can be concluded that the ethanolic extract of leaves of Verbascum thapsus exhibited significant antidiabetic activity via phytochemical (Flavonoids, Alkaloids, Tannins) constituents, antioxidant property of the extract. Histopathological study, $\beta$-cells 
protective effect in alloxan-induced diabetic rats. The study validates the traditional use and shows a possible beneficial role of Verbascum thapsus remedy diabetic mellitus. Further study is required for the evaluation of mechanism of action.

\section{Conflict of Interests}

None Declared.

\section{Funding}

None Declared.

\section{References}

1. Bell GI. Molecular defects of diabetes mellitus. Diabetes 1991; 40: 413-416.

2. Jahangir MA, Imam SS, Kazmi I, et al. Type 2 Diabetes Current and Future Medications: A Short Review. Int J Pharm Pharmacol 2017; 1: 101.

3. Afifi FU, Al-khalid A, Khalil E. (2005). Studies on the in vivo hypoglycaemic activities of two medicinal plants used in treatment of diabetes in Jordanian traditional medicine. $\mathbf{J}$ Ethnopharmacol 2005; 100: 314-318.

4. Ahmed I, Goldstein B. Diabetes mellitus. Clin Dermatol 2006; 24: 237-246.

5. Dinneen SF. What is diabetes? Medicine 2006; 34: 45-46.

6. Bioactive compounds in plants-benefits and risks for man and animals, The Norwegian Academy of Science and Letters, (http://www.dnva.no/geomed)

ISBN 978-82-7099-583-7, Printed in Norway 2010 by AIT Otta AS.

7. WHO/IDF. Report of consultation: Definition, diagnosis and classification of diabetes mellitus and its complications, Geneva, World Health Organization, 1999.

8. Faheemuddin MD*, Ahmed A, Kumar S, et al. Antidiabetic Activity of Methanolic Extract of
Polygonum glabrum Wild Leaves in Diabetic Rats. IJPRS 2016; 5: I-1.

9. Standardization and preliminary phytochemical screening, Practical pharmacognosy, $19^{\text {th }}$ edition, 149-156.

10. Sen S, Chakraborty R, Sridhar C, et al. Free radicals, antioxidants, diseases and phytomedicines: current status and future prospect. Int J Pharm Sci Rev Res 2010; 3: 91100.

11. Riaz M, Zia-Ul-Haq M, Hawa Z, et al. Common mullein, pharmacological and chemical aspects; Rev Bras Farmacogn 2013; 23: 948-959.

12. Pal H, Kumar $\mathrm{T}$, Himani Karki. In vitro antioxidant and renoprotective potential of methanolic extract of Verbascum thapsus leaf in rats. Der Pharmacia Sinica 2013; 4: 14-23.

13. King AJ. Review on the use of animal models in diabetes research. Br J Pharmacol 2012; 166: 877-894.

14. Djomeni PD, Tedong L, Asongalem E, et al. Hypoglycemic and antidiabetic effects of root extract of Ceiba pentandira in normal and diabetic rats. Afr J Tradit Complement Altern Med 2006; 3: 129-136.

15. Faizal P, Suresh S, Kumar RS et al. A study on the hypoglycemic and hypolipidemic effects of an ayurvedic drug Rajanyamalakadi in diabetic patients. Indian J Clin Biochem 2009; 24: 82-87.

16. Maniyar $\quad \mathrm{Y}, \quad$ Bhixavatimath $\mathrm{P}$. Antihyperglycemic and hypolipidemic activities of aqueous extract of Carica papaya Linn. leaves in alloxan-induced diabetic rats. $\mathbf{J}$ Ayurveda Integr Med 2012; 3: 70.

17. Ahmed MF, Kazim SM, Ghori SS, et al. (2010). Antidiabetic activity of Vinca rosea extracts in alloxan-induced diabetic rats. Int $\mathbf{J}$ Endocrinol 2010.

18. Gomathi V, Jayakar B, Kothai R, et al. Antidiabetic activity of leaves of Spinacia oleracea Linn. Alloxan induced diabetic rats. J Chem Pharm Res 2010; 2: 266-274. 
This manuscript was peer-reviewed

Mode of Review: Single-blinded

\section{Editor: Dr. Subhashree GR}

International Journal of Pharmaceutics and Pharmacology is an open access, peer reviewed journal published by Edwiser International.

Submit your valuable manuscript at-

editor.ijpp@edwiserinternational.com

submit.manuscript@edwiserinternational.com

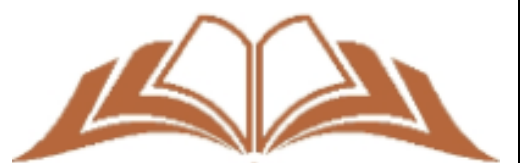

$\mathrm{E} D \mathrm{~W} \theta \mathrm{\theta} \mathrm{ER}$
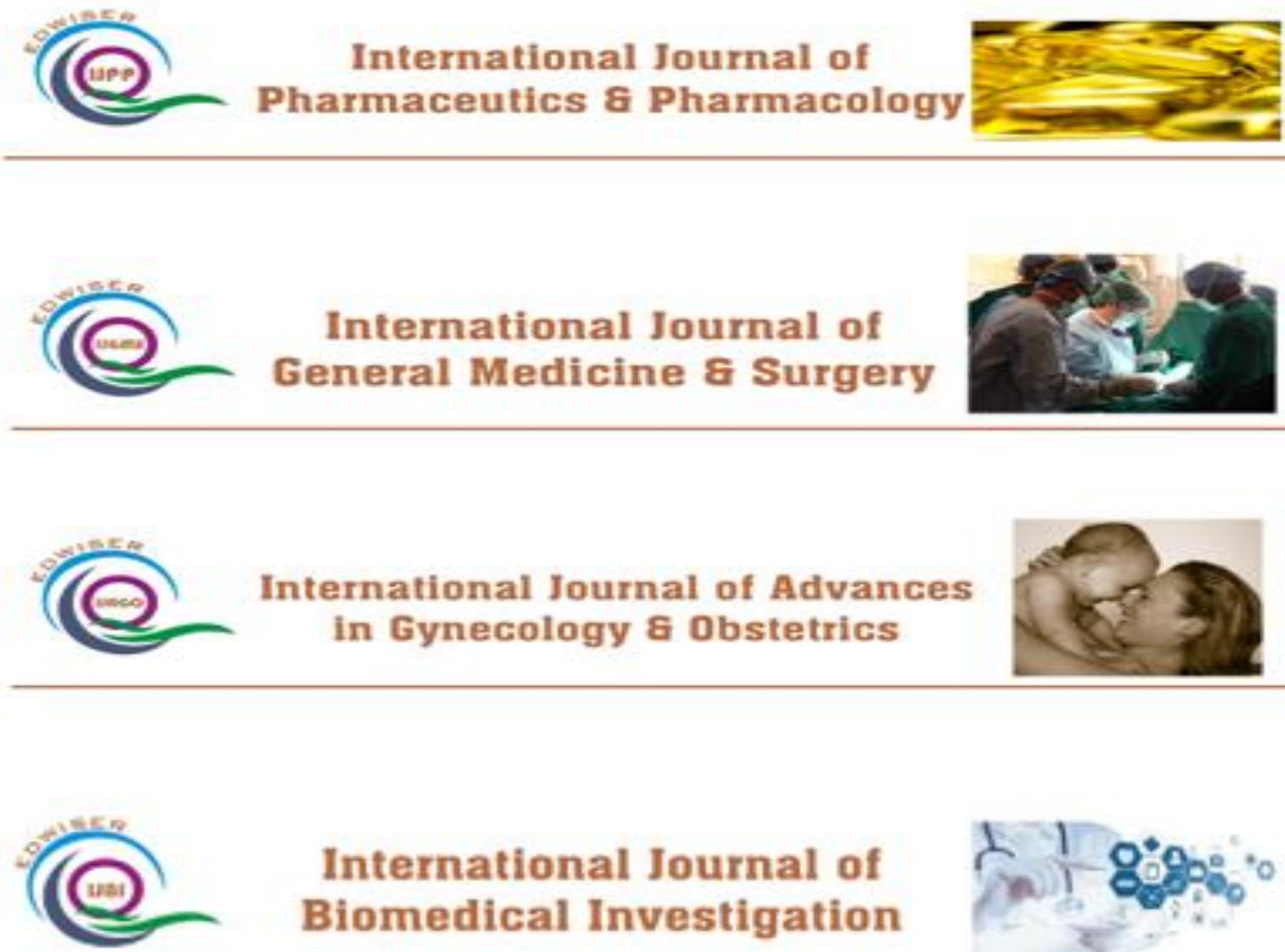

International Journal of Biomedical Investigation
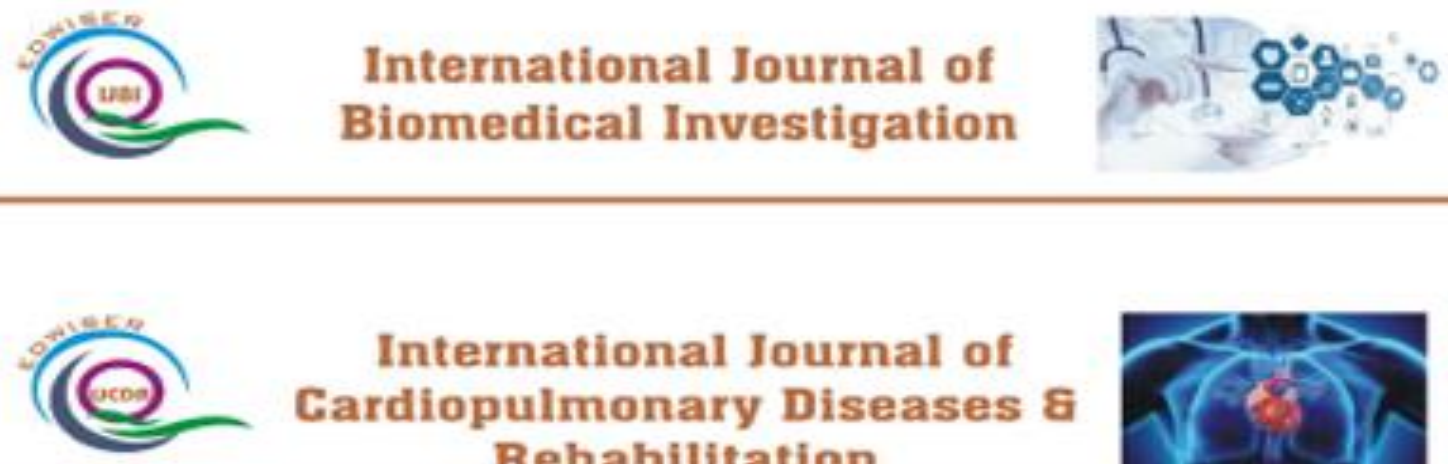

International Journal of Cardiopulmonary Diseases \& Rehabilitation

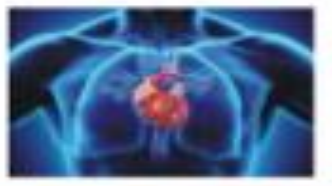

